\title{
Dos Relatos Reflexivos do Estágio Supervisionado em Língua Portuguesa: a questão do regime enunciativo
}

\author{
João de Deus LEITE* \\ Carmen AGUSTINI**
}

\begin{abstract}
* Mestrado (2010) e de Doutorado (2015) em Estudos Linguísticos pela Universidade Federal de Uberlândia. É membro do Grupo de Pesquisa e Estudos em Linguagem e Subjetividade (GELS) e do Grupo de Estudos em Línguagem e Psicanálise (GELP). Contato: joaodedeusleite@hotmail.com.

** Mestrado (1999) e Doutorado (2003) em Linguística pela Universidade Estadual de Campinas. Atualmente é professora associada na Universidade Federal de Uberlândia. Contato: carmen.agustini@gmail.com.
\end{abstract}

\begin{abstract}
Resumo:
À luz das teorizações de Benveniste sobre enunciação escrita, problematizamos e analisamos o modo como uma acadêmica do Curso de Letras: Língua Portuguesa e suas Literaturas de uma instituição federal produz seus "relatos reflexivos” do Estágio Supervisionado em Língua Portuguesa. Estamos considerando que, no tempo da escrita, a acadêmica, já na condição de locutora, precisa lidar com as coerções implícitas e explícitas do gênero "relato reflexivo", que integra o gênero "relatório final", e com as coerções da "situação de discurso", tendo por base a contingência da sala de aula. Dessa maneira, por meio da escrita, a acadêmica (re)elabora a sua experiência no Estágio Supervisionado, dado o processo de metaforização, que se constitui a partir de três tempos que compõem a narratividade da experiência: o tempo do fato vivido, o tempo da escrita e o tempo da leitura. As análises, pautadas em recortes discursivos, mostram os pontos de dispersão da escrita da acadêmica, já que, ao relatar a experiência supostamente exitosa no Estágio Supervisionado, pontos de contradição marcam o regime enunciativo das enunciações escritas da acadêmica, deixando flagrar seu processo de identificação com certos espaços de interpretação que o regime enunciativo implica.
\end{abstract}

\section{Palavras-chave:}

Enunciação escrita. Estágio Supervisionado. Regime Enunciativo.

Signum: Estudos da Linguagem, Londrina, v. 21, n. 3, p. 346-366, dez. 2018 


\section{Dos Relatos Reflexivos do Estágio Supervisionado em Língua Portuguesa: a questão do regime enunciativo}

João de Deus Leite; Carmen Agustini

\section{INTRODUÇão}

Neste artigo, ocupamo-nos da análise de três relatos reflexivos produzidos por uma acadêmica do Curso de Letras: Língua Portuguesa e suas Literaturas de uma instituição federal. Esses relatos integram o relatório final dos Estágios Supervisionados curriculares. No caso do referido curso, a estrutura curricular contempla a realização de quatro etapas de Estágio Supervisionado, perfazendo uma carga horária total de 420 horas. Na primeira etapa, o foco do Estágio Supervisionado é inserir o acadêmico na instituição escolar, de modo que ele caracterize a escola do ponto de vista estrutural, funcional e pedagógico. Além disso, o acadêmico observa a aula de um professor de Língua Portuguesa durante um período. Nas outras etapas, o objetivo do Estágio Supervisionado é inserir o acadêmico no espaço de sala de aula, de maneira que ele observe e ministre aulas sob a supervisão do professor do Estágio Supervisionado e sob o acompanhamento do professor titular da turma foco da realização do Estágio. Cada uma dessas quatro etapas compreende 75 horas destinadas às atividades práticas e 30 horas relativas às aulas teóricas.

Ao final de cada etapa do Estágio Supervisionado, os acadêmicos elaboram o relatório final, no qual descrevem e fundamentam a realização das atividades do Estágio. No caso das três últimas etapas, eles precisam tematizar os momentos de observação e de regência, circunstanciando o modo como as aulas de Língua Portuguesa ocorreram, por se tratar da etapa de regência, isto é, do momento em que eles assumem o lugar social de professor e, por decorrência, precisam assumir um lugar de fala do qual responder pela articulação entre teoria e prática se mostra importante. Essa circunstância constitui o ponto nodal do relatório, já que o acadêmico é levado a relatar ali sua vivência nas práticas profissionais relativas à docência no espaço político-simbólico escolar, buscando construir uma experiência em que ele vivencie a passagem da teoria à prática, e vice-versa. Em outros momentos (cf. AGUSTINI; LEITE, 2016), desenvolvemos a ideia de que essa passagem tem como fundamento a enunciação. É preciso que o acadêmico promova o revezamento enunciativo entre teoria e prática, pautando-se na concepção de que há um limite e de que há certas aberturas entre teoria e prática que são relativos e circunstanciais, ou seja, são contingenciais à sala de aula naquilo que ela oportuniza de relação discursiva entre professor-saber-aluno.

No relatório final, o acadêmico, já no tempo da escrita dessa experiência vivida durante a observação e a regência, tem que lidar com as coerções (im)postas pelas condições 
de produção do relatório. Dito de outro modo, o momento vivido é apropriado e transformado em pensamento, de tal modo que ele possa ser exprimível e mobilizado em outros momentos; inclusive, no momento da escrita. Tal é necessário para que esses sentidos "pensados" possam tomar parte nas redes de memória.

Derivamos de nossa compreensão do pensamento de Granger (1965) considerações para pensar a relação do acadêmico com a escrita do relatório final do Estágio Supervisionado, justamente porque esse autor teorizou sobre a estruturação da experiência na ciência. De acordo com Granger (1965), a ciência, como prática de produção de conhecimento, necessita traçar como objeto aquilo que é passível de ser visado e conhecido; necessita, também, fundamentar a proposição desse objeto por meio da construção de relações que definam a sua estrutura. Essa estrutura, na perspectiva de Granger (1965), não é plena nem absoluta; ao contrário, é parcelar e relacional. Assim, a significação está a serviço das relações residuais que restam da tentativa de promover um fechamento do objeto, ainda que tal fechamento seja relativo e circunstancial.

No caso do acadêmico que precisa passar da experiência à sua metaforização escrita no Estágio Supervisionado, a complexidade presentifica-se no e pelo jogo coercitivo a que ele está exposto: as coerções relativas ao gênero "relatório final", considerando a escrita do "relato reflexivo", e as coerções relativas à situação de discurso, considerando a contingência da sala de aula, vivida na observação e na regência, e as condições sócio-históricas e ideológicas a ela implicada. Trata-se de uma experiência que passa pelo processo de sua escrita. Essa passagem coloca em cena um processo de simbolização que conta com dois aspectos: a planificação do pensamento, por meio da escrita, é destacada da "riqueza contextual", característica da fala; a escrita constitui-se em um tempo posterior ao fato que ela discursiviza.

Nessa perspectiva, esse processo de metaforização é marcado por três tempos: o tempo do fato; o tempo da escrita e o tempo da leitura. No tempo do fato, o acadêmico vivencia a experiência de assumir o lugar de professor e a necessidade de relacionar teoria e prática, de modo a provocar o acontecimento da aula de Língua Portuguesa. Essa apropriação é relacional e circunstancial.

No tempo da escrita, o acadêmico necessita simbolizar o fato vivenciado e suas circunstâncias por meio da escrita. Essa simbolização está em função, inclusive, da tentativa de o acadêmico se fazer compreender por seu leitor-interlocutor: o professor do Estágio Supervisionado. Para tanto, ele precisa, nesse processo, fazer "abstrações de alto grau" (BENVENISTE, 2014, p. 128) e planear seu dizer, conforme o funcionamento semiológico da escrita e a imagem que faz do professor, da experiência vivida e das condições avaliativas nas quais o relatório está implicado. Como se trata de uma avaliação, há uma coerção implícita de que o relato deva conter a narratividade ${ }^{1}$ feliz de uma experiência exitosa. No entanto, é

\footnotetext{
${ }^{1}$ Orlandi (2016, p. 13) define "narratividade como a maneira pela qual uma memória se dizem processos identitários, apoiados em modos de individuação do sujeito, afirmando/vinculando seu pertencimento a espaços de interpretação determinados, consoantes a específicas práticas discursivas".
} 
comum observarmos uma escrita contraditória, porque nem sempre essa experiência é vivida como bem-sucedida, e o acadêmico, identificado a certo espaço de interpretação que diz que ele deve relatar uma experiência feliz para ser aprovado, é impelido a fantasiar essa experiência, ou seja, a buscar na memória discursiva os traços que assim possam significá-la.

No tempo da leitura, que já é uma projeção construída no tempo da escrita, o acadêmico, inserido em certos processos de identificação, é levado a antecipar o que ele pode e deve relatar ao professor e, assim determinado, compõe sua escrita. Sua escrita é, então, habilitada por esse jogo coercitivo. Dessa forma, ante a demanda de elaboração do relatório final, a escrita do relato reflexivo oportuniza a invenção nesse espaço coercitivo, de modo que essa escrita individua o acadêmico, singularizando-o.

É preciso considerar, então, que as condições coercitivas nas quais o relato reflexivo do relatório final do Estágio Supervisionado é produzido determinam a metaforização da experiência docente vivida no processo de sua escrita e de sua narratividade. O relatório é parte integrante das atividades do Estágio, e o professor do Estágio o avalia e lhe atribui uma nota. Essas coerções levam o acadêmico a relatar sua experiência docente vivida como exitosa a partir daquilo que as redes da memória discursiva trazem de condições de interpretação. Assim, o relato ganha uma forma sob a qual é preciso que o professor avaliador coloque atenção para não ser pregado ao que é dito e perceba os pontos em que o acadêmico é 'pinçado' pelo equívoco. Assim, é possível avaliar a tensão da sala de aula e o modo como o acadêmico lida, no processo de metaforização de sua experiência, com o que lhe 'desestabiliza'.

O professor de Estágio Supervisionado do Curso de Letras deve estar interessado, entre outros aspectos, no modo como o acadêmico descreve, problematiza e fundamenta a maneira como a aula de Língua Portuguesa acontece na educação básica; inclusive, é muito demandado que os acadêmicos observem e problematizem a metodologia de ensino do professor e a sua própria metodologia em relação, principalmente, às questões relativas aos gêneros de texto, uma vez que os Parâmetros Curriculares Nacionais (PCN) de Língua Portuguesa orientam para a necessidade de o ensino se embasar em diferentes gêneros de texto, com a prerrogativa de que, assim procedendo, estaria aproximando o ensino da realidade social.

A partir das referidas considerações, adotamos a perspectiva de que há condições enunciativas para que o acadêmico elabore o seu relatório. A escrita do acadêmico precisa, por exemplo, produzir decorrências para os fundamentos teóricos discutidos no espaço de sala de aula da universidade, tendo por base a carga horária teórica do Estágio, ou mesmo os saberes construídos ao longo do curso. Essas discussões compõem a memória passível de serem narrativizadas no relato reflexivo, haja vista que é nessas e por meio dessas discussões que o acadêmico constrói a imagem do professor e do que ele 'defende' como pertinente ou não para a sala de aula. Essa imagem construída determinará o processo de escrita. Em decorrência do exposto, o regime enunciativo de que tratamos neste artigo diz respeito ao modo como a escrita do acadêmico se organiza discursivamente, a partir do processo de identificação do acadêmico com os saberes ali presentificados. 
É necessário ressaltar que, textualmente, até pelas questões do gênero "relatório final" do Estágio Supervisionado, o acadêmico precisa atender ao formato e à composição temática do gênero. Contudo, discursivamente, o acadêmico é levado pelo próprio processo de simbolização a organizar a sua escrita de um modo e não de outro, de modo a atender as condições de interpretação que o acadêmico supõe comporem as expectativas do professor. Embora o acadêmico reconheça as coerções (im)postas pelas condições desse relato, as operações linguísticas que lhe dão forma permanecem na ordem do inconsciente. Assim, o acadêmico supõe produzir um relato coerente. No entanto, conforme mostraremos nas análises, há um jogo opositivo que dá relevo à tensão vivida em relação à contingência da sala de aula.

Neste artigo, tratamos das coerções relativas ao gênero "relato reflexivo", que, como já dissemos, compõe o gênero "relatório final" do Estágio Supervisionado. Os relatos analisados figuram como uma seção dos relatórios finais, tendo por base o percurso de uma aluna do Curso de Letras: Língua Portuguesa e suas Literaturas. Sendo assim, as coerções do gênero e da situação de discurso específica na qual ele está implicado, e da qual tratamos, referem-se à necessidade de o acadêmico tematizar e problematizar a experiência vivida na realização das etapas de observação e de regência. A escrita do relato reflexivo, conforme destacam alguns teóricos filiados à Linguística Aplicada, como Signorini (2006), assume a função de dar voz ao futuro professor e de possibilitar a autorreflexão sobre a sua própria prática. O olhar avaliativo do professor do Estágio Supervisionado da acadêmica em questão está ancorado nesses pressupostos da Linguística Aplicada e essa posição assumida pelo professor determina a narratividade do relato, como veremos. Assim, a complexidade da escrita do relato assume outros contornos sócio-históricos e ideológicos.

Uma dessas coerções diz respeito à necessidade de o acadêmico ter de promover, já no espaço de sala de aula, a articulação entre teoria e prática e, no tempo da escrita, ter de enunciar sobre a articulação (re)produzida em função da posição assumida pelo professor do Estágio Supervisionado. Essa articulação é relativa e circunstancial aos processos de identificação dos sujeitos participantes da enunciação, embora seja sócio-histórica e ideologicamente determinada. E a passagem de uma a outra está em função dos limites e das aberturas que a relação entre a teoria e a prática promovem no revezamento enunciativo. $\mathrm{O}$ acadêmico precisa tematizar e problematizar essa passagem, mobilizando argumentos consistentes e fundamentados de acordo com o que supõe ser a posição do professor do Estágio Supervisionado.

\section{Enunciação Escrita e Regime Enunciativo}

Na perspectiva de Benveniste (2014), a escrita é sempre a escrita de um sujeito e, por isso, projeta o sujeito que a (re)produz, de modo que o sujeito é o próprio efeito que sua escrita produz no outro. Isto significa, para dizermos do foco deste artigo, que estamos diante de um processo complexo no qual estão implicados as condições de interpretação e 
o processos de identificação dos participantes: o aluno e o professor. Por isso, de nosso ponto de vista, é inalienável a consideração das condições sócio-históricas e ideológicas que determinam a produção escrita do relato e o modo como elas afetam as abstrações de alto grau do processo de escrita. Por conseguinte, toda escrita é complexa e "supõe uma série de abstrações” (BENVENISTE, 2014, p. 130). Nas próprias palavras de Benveniste:

Uma primeira grande abstração reside, assim, no fato de que a língua se torna uma realidade distinta. [...] A abstração consiste, então, em se desvincular da riqueza 'contextual' que, para o falante, é essencial. [...] Ele precisa falar de coisas fora das circunstâncias que fazem com que tenhamos necessidade de falar, já que, para ele, são realidades vivas. [...] Trata-se de uma língua que não é proferida nem aos colegas nem a seus pais, uma língua que não sabemos nem quem fala nem quem escuta (BENVENISTE, 2014, p. 130).

Denominada por Benveniste (2014, p. 128) língua escrita, a língua da escrita não é a língua da enunciação falada; a língua escrita possui, portanto, sua própria condição e realidade. Ela preconiza um sujeito que a (re)produza; o locutor apropria-se da língua escrita e a maneja, de modo a torná-la apta a dizer, nas condições sócio-históricas e ideológicas de sua escrita, (d)a narratividade que concerne à situação de discurso. Portanto, a escrita não é somente a língua sob a forma escrita, porque ela (com)porta a escrita de um sujeito.

A escrita, assim compreendida, (pres)supõe o estabelecimento de uma configuração enunciativa, a fim de que a relação discursiva possa se efetivar. A escrita é endereçada a um colocutor virtual que é projetado no e pelo mo(vi)mento de escrita no processo que a constitui. Esse mo(vi)mento é possível porque a memória se inscreve na escrita. $\mathrm{Na}$ escrita, instaura-se, dessa forma, um eu-tu-ele-não aqui-não agora. Esse não aqui e não agora permite um retorno ao escrito, de modo que é possível realizar um trabalho elaboral sobre ele. O escrito é para um alhures ao mo(vi)mento de sua (re)produção. Isso implica uma necessidade outra de elaboração textual das coordenadas referenciais de pessoa(s), tempo e espaço.

A configuração enunciativa reclama, por sua vez, um regime enunciativo, que orienta o modo como a transposição da língua em escrita pode e deve acontecer. A “colagem” dos aspectos teóricos e práticos aos aspectos da experiência vivida estão em função da narratividade que a configuração enunciativa convoca. É a configuração enunciativa que baliza as operações linguísticas em funcionamento no estabelecimento da relação discursiva. Nesse sentido, embora o regime enunciativo seja tributário ao gênero textual, ele é determinado pela situação de discurso.

No caso do relato reflexivo presente em relatórios finais de Estágio Supervisionado de cursos de licenciatura, é necessário que a teoria a ser mobilizada na avaliação da prática vivida não só faça parte, de algum modo, da memória discursiva convocada, mas também esteja, imaginariamente, atestada pela posição do professor do Estágio Supervisionado. Essa condição transparece na escrita do relato como imperativo para a sua avaliação exitosa. Dito de outra forma, o próprio mo(vi)mento de escrita do relato "força" o acadêmico a inscrever o seu relato naquilo que ele supõe ser o que o professor do Estágio Supervisionado consideraria exitoso para a situação relatada. 
Essa “colagem", no entanto, no mo(vi)mento de planificação do escrito, apresenta fissuras, que deixam flagrar a tensão e a contradição vividas pelo acadêmico no processo de escrita do relato. Essas fissuras constituem marcas discursivas da determinação do regime enunciativo que está em funcionamento. Elas mostram o "conflito" da experiência com as coerções do seu processo de metaforização. Isto não implica dizer que o acadêmico estaria mentindo em seu relato; ao contrário, significa dizer que ele é impelido a tentar encontrar uma saída bem-sucedida mesmo para aquilo que ele experiencia como problemático ou como fracasso.

Daí aparecerem relações "estranhas" como: a aluna ficar fora da sala de aula e isto ser bom para aplicar um método específico. Em que essa situação poderia ter ajudado na aplicação do tal método? Essa explicação não é explicitada no relato e, de nosso ponto de vista, dificilmente o seria, porque essa explicação daria a ver o não exitoso da experiência vivida. Sem poder dizê-lo, a relação "estranha” (im)põe-se como uma saída para alcançar a valoração exitosa. É sobre esses mo(vi)mentos de metaforização da experiência que nossa análise se volta, a fim de mostrar a determinação do regime enunciativo sobre o processo de escrita do relato.

\section{Da Constituição do Regime Enunciativo em Enunciações Escritas: o relato reflexivo do Relatório de Estágio Supervisionado}

Nesta seção, analisamos os três relatos reflexivos que uma acadêmica elaborou ao final de cada etapa de observação e de regência do Estágio Supervisionado no Curso de Letras: Língua Portuguesa e suas Literaturas de uma instituição federal. Com base nesses três relatos, mostraremos o modo como as enunciações escritas da acadêmica em questão organizam-se discursivamente, considerando as coerções do gênero "relato reflexivo" e as coerções da situação de discurso. Estamos tomando essa organização discursiva sob a condição do regime enunciativo, conforme já salientamos, visto que a escrita encerra um processo complexo de metaforização da experiência vivida. Trata-se de uma metaforização que não está ao bel-prazer daquele que escreve; ela está em função da narratividade do possível ante às condições de interpretação e os processos de identificação do sujeito. Assim, ela é fruto da dialética da relação entre (1) o tempo do fato, (2) o tempo da escrita e (3) o tempo da leitura.

Os três relatos reflexivos serão analisados, de modo a mostrarmos como se constitui a unidade da experiência e a unidade da estruturação da experiência no Estágio Supervisionado da acadêmica em questão. Dos relatos reflexivos, selecionamos recortes discursivos (RD) para construirmos a análise e, posteriormente, as relacionaremos entre si. Cada relato reflexivo é analisado em um tempo, já que, a cada etapa vivenciada do Estágio, as coerções do gênero e da situação de discurso são específicas. É preciso destacarmos que a quantidade de recortes discursivos, por tempo analisado, está em função da extensão do relato reflexivo. 
Para indiciar a unidade da experiência, considerando os relatos reflexivos, privilegiamos o modo como a acadêmica (1) discursiviza e (2) predica a sua experiência na etapa de observação e de regência no Estágio Supervisionado. Além disso, salientamos o modo como ela (3) valora o seu desempenho na regência das aulas de Língua Portuguesa propriamente ditas. Os pontos (1), (2) e (3) estão em função das coerções do gênero em questão. O olhar avaliativo do professor, em seu caráter intersubjetivo, porta, na relação professor-acadêmica, as insígnias dessas coerções. Desse modo, estamos assumindo que a acadêmica escreve para o outro na necessidade de dizer ou de silenciar os fatos vividos, buscando (re)construir certos sentidos.

Para indiciar a unidade da estruturação da experiência, contemplamos o modo como a enunciação escrita da acadêmica faz trabalhar uma dispersão daquele que escreve naquilo que enuncia. Essa dispersão pode ser pensada, por exemplo, em termos de contradição que a enunciação escrita faz materializar, já que a condição de escrita do acadêmico é lidar com as coerções do gênero e da situação de discurso. Essas coerções operam efeitos diferentes, pois o modo como a memória se inscreve na metaforização da experiência reclama uma narratividade específica. Uma outra forma de a dispersão funcionar é por meio do silenciamento ou do apagamento de aspectos demandados pelas coerções e que, contudo, não ganham uma textualização expressa. $\mathrm{O}$ jogo entre unidade e dispersão mostra a complexidade do processo de metaforização da experiência, de maneira que esta precisa ser elaborada, exprimível e mobilizada em outros momentos.

Consideremos, a seguir, os três tempos de análise.

\section{Primeiro Tempo}

Vejamos o primeiro recorte discursivo (RD1) de nosso trabalho de análise:

(RD1) Minha primeira experiência com regência em sala de aula, (sic) foi no ensino fundamental em uma escola municipal na periferia da cidade, na qual as crianças são muito carentes./ A partir de minha prática, pude observar os diferentes ritmos de aprendizagem de cada criança, onde a grande maioria consegue acompanhar as explicações, participando ativamente das aulas, porém, nota-se que algumas crianças não conseguem assimilar as informações e acompanhar o desempenho da turma com isso retraem-se e elevam seu filtro afetivo./ Dentre as crianças apontadas como 'problemáticas', havia algumas que ainda não conheciam todas as letras do alfabeto, não conseguem juntar as letras formando sílabas e consequentemente formar frases, não conhecem as cores, os numerais, não tem noção do que está perto ou longe dentro ou fora, acima ou embaixo etc. ${ }^{2}$

(Relato reflexivo sobre o Estágio Supervisionado em Língua Portuguesa II)

\footnotetext{
${ }^{2} \mathrm{O}$ uso de barras serve para marcar a paragrafação do texto do relato reflexivo da acadêmica.
} 
Considerando a enunciação escrita em RD1, é perceptível que a relatora salienta que a realização da etapa de regência do Estágio Supervisionado II oportunizou a ela a primeira experiência em sala de aula propriamente dita. Ela marca, já no primeiro parágrafo de seu relato, que a escola onde estagiou é de periferia e que o público-alvo da escola é carente. A relação de adjetivação e de adverbialização "muito carentes", no mo(vi)mento de descrição, reclama diversas condições de interpretação que sugerem, de saída, que sua primeira experiência foi afetada pelas dificuldades que os discursos sobre educação e ensino circulam em nossa sociedade. Assim, esse mo(vi)mento pode produzir efeitos de defesa antecipada, embora, na escrita do relato, essa especificação não receba uma fundamentação em termos de argumentatividade. Assim, é possível questionar: a relatora baseia-se tão somente em sua observação? A relatora pauta-se em informações obtidas a partir de conversa com profissionais da escola? 'Trata-se de questões que permanecem em aberto, já que a relatora não mobiliza argumentos para referendar sua especificação.

$\mathrm{Na}$ sequência de seu relato, a relatora, por meio da expressão "a partir de minha prática", marca a perspectiva de que foi a prática dela que a possibilitou observar a diferença de ritmos de aprendizagem que cada aluno tem. Se considerarmos os efeitos de sentido dessa expressão, notadamente da locução gramatical “a partir", que serve para demarcar o início de ordenamento de uma ideia, podemos destacar que a relatora absolutiza a instância da prática. Nessa perspectiva, há o silenciamento de teorias que preconizam o princípio de que a aprendizagem é desigual e heterogênea em uma turma de alunos, por exemplo. Outro efeito possível é o de que, por meio da prática, ela pode constatar essa diferença. A despeito dos efeitos de sentido que esse enunciado pode provocar no interlocutor, a relatora cai em contradição na sequência, porque, primeiro, enuncia que cada criança tem seu ritmo e, depois, afirma que "a grande maioria consegue acompanhar as explicações, participando ativamente das aulas, porém, nota-se que algumas crianças não”. Nesse recorte, evidencia-se que um conjunto significativo de alunos está no mesmo ritmo, enquanto apenas alguns não. Essa afirmação evoca a padronização das fases da vida, discurso fortemente aventado por várias perspectivas psicológicas sobre o desenvolvimento humano.

A relatora passa a especificar a ideia de que há alunos que dão conta de acompanhar as aulas, o que resulta na participação deles, e de que há alunos que não dão conta de aprender e que, por isso, não participam da aula. Assim, a relatora atribui a não participação na aula a uma questão do aluno e não da aula ou dela, já que eles não dão conta de "assimilar as informações e acompanhar o desempenho da turma”. Com base nessa última especificação, a relatora elabora a conclusão de que esses últimos alunos "retraem-se e elevam seu filtro afetivo". Chama-nos a atenção o modo como ela nomeia o suposto estado de introspeção dos alunos. Por meio da designação "filtro afetivo", marca-se qual perspectiva? A de que os alunos se alteram, emocionalmente, e passam a ficar seletivos? A de que os alunos se alteram, psicologicamente, e não interagem com os outros alunos? Ademais, a participação na aula passa a ser medida pela afetividade e não mais pela capacidade de aprendizagem do aluno, o que denota um deslizamento de sentidos na descrição-interpretação-argumentação da relatora. 
Se, antes, ao discursivizar o perfil de aluno que acompanha as aulas, a relatora marcava a ideia de que eles, de fato, participam; agora, ela passa a mostrar o outro perfil de aluno, aqueles que não participam. Na menção ao primeiro perfil, ocorre o advérbio de modo "ativamente", que produz o efeito de ênfase sobre o modo como os alunos participaram. Já na menção ao segundo perfil de aluno, ocorrem os verbos "retrair" e "elevar", que aparecem integrados a outros termos, expressando a consequência da não participação dos alunos descritos nele. A alusão a esses dois perfis de aluno, tendo como critério de abordagem aspectos da afetividade, é consoante à perspectiva de muitos estudos inscritos no âmbito da linguística aplicada. É que se busca explicar a relação entre "cognição" e "afetividade" em situações de aprendizagem em sala de aula, demonstrando de que modo a afetividade afeta a aprendizagem. E a relatora mostra-se alinhada a essa perspectiva.

No fluxo da escrita, passa a tematizar o caso de crianças que apresentam uma demanda mais especial em relação às demais. Cabe salientar que a turma em que a acadêmica estagiou é composta de alunos com necessidades especiais. Na época, em 2008, o estado do Tocantins estava implantando a "sala de recursos" para atender, com aparato pedagógico específicos, os alunos com esse perfil. A relatora destaca que aquelas crianças não possuem certas habilidades pressupostas para alunos do $5^{\circ}$ ano escolar. Habilidades como: identificar as letras que compõem o alfabeto da Língua Portuguesa; integrar as letras entre si, de modo a formar palavras e, por sua vez, integrar as palavras para formar frases; identificar cores e numerais, tendo por base algum ponto de referência, de maneira a identificar o está "perto", "longe", "fora", "acima" e "embaixo".

A bipartição dos alunos produz um contraste, e esse contraste sugere que as crianças problemáticas não devem estar na mesma sala que as crianças que participam ativamente. A enumeração de conhecimentos básicos que elas não teriam domínio ainda reforça essa interpretação, embora ela não a assuma explicitamente; ela permanece como efeito da descrição feita. Assim, a relatora isenta-se de tomar posição sobre o que diz ao (se) enunciar.

Chama-nos a atenção a ocorrência da expressão "apontadas como "problemáticas" em referência às crianças com uma demanda de aprendizagem mais acentuada. $\mathrm{O}$ verbo "apontar", na forma nominal do particípio, produz o efeito de sentido de que a consideração e a rotulação "crianças problemáticas" não é uma construção da relatora. Há um agente de atribuição prévio. A ocorrência das aspas em "problemáticas" parece acentuar um ponto de dispersão em sua enunciação escrita. Essas aspas colocariam em suspensão certo semantismo social entre a rotulação "crianças com necessidades especiais" e "crianças problemáticas"? Com as aspas, manter-se-ia certa distância em relação aos sentidos negativos que a palavra "problemática" comporta?

Com a questão da "inclusão escolar", sobretudo com a perspectiva problematizadora de muitos estudos inscritos na área da educação e na área da linguística aplicada, a menção e a consideração de "necessidades especiais" como "problema" figura como equívoco. Na narratividade da relatora, essas questões apresentam-se como aspectos que marcam o êxito da experiência, uma vez que elevam a complexidade e a dificuldade da situação vivida e, 
independente disso, a experiência foi exitosa; ela afirma ter conseguido cumprir o propósito do Estágio. Vejamos o próximo recorte discursivo:

(RD2) Após um diálogo com a professora regente da sala de recursos, tomamos conhecimento das principais dificuldades daqueles alunos, e partindo do principio (sic) de que todos são dotados de inteligência, nos dispomos a colaborar com aquele trabalho, dando nossa contribuição enquanto estagiárias./ Os alunos que recebem acompanhamento na sala de recursos, todos são matriculados na rede regular de ensino, cumprindo com a proposta do ministério da educação que é a inclusão social, inserindo o aluno no convívio com outras pessoas valorizando e estimulando a troca de experiências./ É importante relatar que o atendimento dispensado a esses alunos, (sic) é realizado em horários opostos aos da sala regular, onde em consonância com a equipe de educadores são trazidos, (sic) as principais deficiências dos alunos os quais serão trabalhados criteriosamente dentro das devidas possibilidades./ Já conhecedoras das deficiências daqueles alunos, uma das nossas maiores preocupações foi em elaborar materiais procurando sempre adequá-los às necessidades dos alunos, os quais se mostraram bastantes interessados pelas inovações. Para não tornar tão exaustivas as aulas, também conciliamos na programação um momento para recreação, com brincadeiras, jogos, dinâmicas, pois consideramos esse momento importante para a interação e socialização entre os alunos./ Nossa metodologia de trabalho a meu ver, (sic) foi bastante produtiva, pois conseguimos um relacionamento harmonioso, onde os alunos logo se mostraram interessados pelos exercícios e programações que propusemos./ Apesar do pouco tempo que convivemos com essa dimensão do ensino, foi possível perceber a importância desse trabalho, assim como nos fez despertar para também lutar pela capacitação de empreendimento e reconhecimento do mesmo, de forma que possamos sanar as desigualdades proporcionando um melhor atendimento as pessoas portadoras de deficiências./ Das literaturas que consultei sobre inclusão social e Educação especial, considero importante o que citou MAZZOLA, 2005. p. 102: 'declara-se que a nova proposta se inscreve como dimensão da nova política social brasileira, pautando-se na perspectiva de participação conjunta do governo e da sociedade para o alcance da meta primordial da educação especial: a universalização, através da democratização do ensino'./ Para concluir destaco que é nosso papel como educadores buscar políticas de inclusão, e fazer com que a educação especial em sala de aula de recursos realmente seja 'especial' procurando segmentar, organizar, a fim de se atuar no sentido da provisão dos recursos necessários para o bom desempenho desta modalidade de ensino, no conjunto das ações voltadas para a universalização do mesmo.

(Relato reflexivo sobre o Estágio Supervisionado em Língua Portuguesa II) 
Nessa parte do relato da acadêmica, é observável que o seu dizer "prega-se" a um discurso muito difundido em nossa sociedade. Esse discurso aventa que falta ao professor recursos didáticos adequados para ensinar, de tal modo que, suprida essa falta, o ensino aconteceria. Institui-se, dessa forma, uma relação de condicionalidade, que apaga qualquer outra relação passível de ser ali significada. Assim, ao dizer que produziu material adequado ao ensino dos pronomes para os alunos portadores de necessidades educacionais especiais, faz significar o êxito de sua prática, mesmo sem descrevê-la. De que modo utilizou esses recursos que diz ter produzido? Nessa situação de discurso, o que pode significa "relacionamento harmonioso"? Se este foi conseguido, então antes não havia? Trata-se de uma narratividade marcada por furos na sua tessitura; é, portanto, uma metaforização lacunar. Assim, o relato significa o êxito da experiência em detrimento dos "problemas" encontrados. Trata-se do recorte que a narratividade produz em função das coerções sofridas pela acadêmica.

Outro discurso bastante presente no relato da acadêmica diz respeito à ludicidade de que o professor deve lançar mão, a fim de cativar o aluno e, assim procedendo, conseguir captar sua atenção para a aula. Assim, é dito que "para não tornar tão exaustivas as aulas, também conciliamos na programação um momento para recreação, com brincadeiras, jogos, dinâmicas". O aspecto lateral do lúdico descortina que a aula não se torna lúdica; é parte do tempo da aula que é utilizado para outras atividades que podem se constituir como lúdicas para o aluno. Assim dito, a aula continua sendo significada como 'exaustiva', restando-nos questionar para quem as aulas seriam "exaustivas": estagiária ou alunos? Ou ambos? Poderíamos, também, pensar nos efeitos de sentido que esse jogo opositivo pode produzir: aula não é recreação, não é brincadeira, não é jogo e não é dinâmica. Aula é trabalho, é seriedade, é preocupação e é monotonia. Nesse jogo opositivo, a aula é significada de modo negativo. De que isto poderia ser sintoma? O que isto poderia dizer da acadêmica, uma vez que o sujeito é o que diz ao (se) enunciar? Dito de outro modo, o que o sujeito diz ao (se) enunciar projeta sua identidade para o outro.

Com base no exposto, podemos dizer que a aula em si permanece silenciada; ela não é descrita, e o relato não consegue dar ciência do que poderia ter acontecido nela. Questionamo-nos: por que a aula é mantida à distância no relato? Que efeitos de sentido esse apagamento pode produzir? Ao final do relato, a acadêmica alerta os professores para a necessidade de "buscar políticas de inclusão, e fazer com que a educação especial em sala de aula de recursos realmente seja 'especial"'. Essa afirmação mostra que a educação especial não funciona; ela ainda não se sustenta em políticas de inclusão, e a educação especial não é especial. Nessa perspectiva, seu dizer configura-se como uma (d)enunciação. Que inclusão é essa que não fornece ao professor material adequado, políticas públicas específicas e que, por isso, não é especial? Embora ela não ousa (d)enunciar, por meio da política do silêncio, vemos ali a menção a discursos que afirmam que a inclusão é, de fato, uma exclusão. Assim, é possível vislumbrar ali o seguinte dizer: colocar junto não é incluir.

Embora haja esse efeito de denúncia, na escrita do relato ressoa, também, o efeito de que, no Estágio realizado pela acadêmica, a educação especial funcionou bem. Isto é 
posto por dois enunciados em particular: (1) "os alunos logo se mostraram interessados pelos exercícios e programações que propusemos" e (2) "apesar do pouco tempo que convivemos com essa dimensão do ensino, foi possível perceber a importância desse trabalho". O argumento (1) é caucionado pelo discurso que apregoa que, com bons e variados materiais, o problema do ensino estaria resolvido. Já o argumento (2) evidencia a capacidade da acadêmica em fazer o ensino acontecer, já que ela, inclusive, produziu os materiais utilizados. Assim, ela, ao ser enganchada nesse discurso, consegue inscrever sua prática em uma experiência exitosa, cumprindo a ordem (im)posta pelo regime enunciativo.

Consideremos, a seguir, o Segundo Tempo de análise.

\section{Segundo Tempo}

Vejamos como a narratividade dessa outra etapa do Estágio Supervisionado acontece e como os seus recortes são determinados pelo regime enunciativo implicado no processo de escrita do relato reflexivo do relatório final do Estágio Supervisionado. Tomemos o recorte discursivo:

(RD3) Realizei a segunda etapa do Estágio Supervisionado em Língua Portuguesa numa Escola Municipal da periferia da cidade. Esta escola enfrenta um grande problema, pois recebe vários alunos provenientes da zona rural, os quais não foram devidamente alfabetizados e na maioria dos casos não sabem nem escrever./ Estas crianças quando inseridas no ensino fundamental na escola urbana não conseguem acompanhar o desempenho estudantil com seus colegas, sentem-se constrangidos por não saberem ler e escrever, situação que desencadeia um grande bloqueio para o desenvolvimento da aprendizagem desses alunos./ Ao iniciar minhas observações percebi as dificuldades enfrentadas pela professora para despertar a atenção dos alunos, que passavam a maior parte do tempo dispersos envolvidos com brincadeiras, e até brigas dentro da sala de aula./ Não difere das muitas outras escolas que já conhecemos o espaço físico é pequeno e pouco arejado, número grandioso de alunos por turma e falta de material didático e pedagógico, o que torna mais difícil a aplicação das aulas./ A professora era calma e possuía, (sic) um certo domínio da sala de aula, porém ainda muito presa ao método tradicional de ensino, centrada no livro didático e sem muitas inovações. Logo pensei o quão seria difícil dominar e chamar a atenção daqueles alunos para que assistissem e participassem das nossas aulas./ Antes de iniciar as observações das aulas fomos visitar a escola duas vezes. Conhecer os professores da disciplina de Português e também a diretora e coordenadora da escola, e numa conversa informal tomamos conhecimento de alguns problemas que estavam acontecendo no bairro e que estavam prejudicando diretamente algumas crianças e adolescentes na referida escola./ O problema era o 
seguinte: alguns jovens viciados em drogas estariam influenciando alguns alunos da escola e isto estava prejudicando a frequência e o aprendizado de tais crianças./ Preocupadas com o problema eu e minha companheira de estágio optamos por trabalhar o conteúdo programático que a professora iria ministrar, 'pronomes' adequando ao tem 'drogas', com o objetivo de chamar a atenção dos alunos para os riscos e malefícios que as drogas desencadeiam na vida de uma pessoa.

(Relato reflexivo sobre o Estágio Supervisionado em Língua Portuguesa III)

Enquanto no primeiro relato - referente ao primeiro Estágio docente realizado pela acadêmica - os alunos portadores de necessidades educacionais especiais foram significados como problema, no segundo relato - referente ao segundo Estágio docente realizado pela acadêmica - os alunos procedentes da zona rural é que são significados como problema. Ambos são apresentados como alunos que não conseguem acompanhar as aulas. Na sequência, prega-se ao discurso da indisciplina dos alunos: "percebi as dificuldades enfrentadas pela professora para despertar a atenção dos alunos, que passavam a maior parte do tempo dispersos envolvidos com brincadeiras, e até brigas dentro da sala de aula". Essa parte do relato é marcada por saltos temáticos: "o espaço físico é pequeno e pouco arejado, número grandioso de alunos por turma e falta de material didático e pedagógico, o que torna mais difícil a aplicação das aulas". Embora enumere os problemas enfrentados pela escola, o último item, "falta de material didático e pedagógico", é apresentado como sendo o maior de todos os problemas. Assim, o segundo relato mantém a tônica do primeiro, inscrevendo-se, predominantemente, no discurso que apregoa que a falta de recursos é o fator de maior peso na inviabilização do ensino. É como se o simples fato de ter material didático e pedagógico resolvesse o problema de ensino. O discurso utilitarista e instrumentalista do neoliberalismo impacta a escrita da acadêmica, uma vez que, de acordo com ela, basta o professor ter bons materiais didático e pedagógicos que o ensino acontecerá. Nesse sentido, o professor seria apenas um treinador para os alunos e um consumidor de materiais.

Outro discurso presente no relato, e que o subsidia, é o discurso doutrinário. Em “optamos por trabalhar o conteúdo programático que a professora iria ministrar, 'pronomes' adequando ao tem 'drogas', com o objetivo de chamar a atenção dos alunos para os riscos e malefícios que as drogas desencadeiam na vida de uma pessoa", o apelo a valores morais é forte. Assim, conjuga-se a matéria a ser ensinada a exemplos doutrinários, cuja função é, além de explicitar uma regra, por exemplo, levar o aluno a agir de determinada forma e não de outra.

Ademais, vale destacar que a acadêmica antecipa as dificuldades que enfrentaria no Estágio docente: "Logo pensei o quão seria difícil dominar e chamar a atenção daqueles alunos para que assistissem e participassem das nossas aulas". E, ao fazê-lo, faz significar que, para a professora regente, é difícil dominar e chamar a atenção dos alunos. Mais à frente, será metaforizada a experiência vivida e, nesse momento, será significada a regência 
como uma experiência exitosa, cumprindo a (im)posição do regime enunciativo. Vejamos o RD4:

(RD4) Terminadas as observações, iniciamos então a regência, tarefa árdua e difícil, pois os alunos já não gostavam de estagiários alegando que todos aqueles que já haviam passado por ali, escreviam longas tarefas e textos na lousa e que eles já estavam cansados de tanto escrever. Logo no primeiro dia de nossa regência uma certa aluna, ficou (sic) fora da sala de aula e disse: - não vou assistir essa aula, porque não é minha professora que vai ministrar, então eu não vou entrar!/ Ao ouvir isto eu fiquei pasma e pensei, estamos perdidas. Mas, esta (sic) fato nos ajudou muito a aplicar o método que havíamos planejado anteriormente, ministrar as aulas com músicas, cartazes, jornais, revistas e até pequenos teatrinhos, sempre enfocando o conteúdo que estávamos ensinando. Para nossa surpresa o método funcionou, e quando colocamos a música para que eles pudessem identificar na letra os 'pronomes' eles ouviram atentos e até cantaram junto./ Em outra aula utilizando um cartaz, pedimos que os alunos observassem as imagens ali aparentes e criassem um texto segundo a imaginação deles. Eles criavam vários tipos de textos narrativos, descritivos etc., claro haviam muitos erros ortográficos e até de concordância, mas pude perceber a capacidade de criação textual, a qual deve ser mais trabalhada em todas as disciplinas, estimulando os alunos a ter senso crítico e criativo./ O decorrer de nossa regência foi bastante produtivo, porque usando uma maneira diferente de aplicar os conteúdos, onde conseguimos mobilizar a grande maioria da turma a participar ativamente discutindo e dando opiniões, a respeito do tema./ Logo conseguimos conquistar o carinho e o respeito dos alunos, aproveitamos bem o tempo que tivemos para ensinar, participamos diretamente com os alunos das atividades comemorativas do calendário da escola, na semana da criança e dia dos professores, fizemos festinhas e realizamos muitas brincadeiras e recreações, os alunos gostaram muito./ Para encerrar nossas atividades de regência, realizamos uma dramatização na própria sala de aula, colocamos as carteiras em forma de círculo e utilizamos o espaço central para apresentação; (sic) para que dessa forma todos pudessem visualizar melhor. A apresentação foi feita com o texto da estória do 'menino que sonhou que tinha rabo de cachorro', com caracterização dos personagens./ Nós enquanto professores precisamos rever nossos conceitos de como ministrar nossas aulas, procurando inovar sempre nossa metodologia, buscando nosso objetivo maior, promover a aprendizagem de nossos alunos de forma menos cansativa e menos tradicional, utilizando diversos recursos como: a música, o teatro etc./ O método que utilizamos para avaliar o aprendizado do conteúdo, (sic) foram os exercícios e a produções textuais realizadas e corrigidas em sala de aula, pois não basta apenas grifar os 'erros' encontrados nas tarefas e nos textos dos alunos, nós devemos corrigir juntamente com eles, retomando o conteúdo se for necessário para que o aluno 
possam (sic) entender./ De toda essa experiência que tive como professora regente de uma sala de aula, percebi que apesar dos desafios e dificuldades que encontramos ainda é possível 'ensinar' e obter uma resposta positiva, e devemos dar a eles o que queremos que eles também nos dêem, (sic) 'carinho e respeito'.

(Relato reflexivo sobre o Estágio Supervisionado em Língua Portuguesa III)

Há pré-construídos que sustentam o relato da acadêmica e que o circunscreve a certos discursos sobre educação em circulação em nossa sociedade. A base de tais discursos é a política neoliberal que transforma a educação e o saber em mercadoria consumível. Assim, a relatora vive a tensão entre "ensinar" e "recrear". Essa tensão é silenciada pela prevalência do discurso lúdico no relato. No entanto, há momentos, como veremos abaixo, em que essa tensão aflora na escrita a despeito da suposta identificação da relatora ao discurso lúdico. Parece que o discurso lúdico é a saída encontrada para que a narratividade se mantenha adequada às coerções do regime enunciativo. Essa "prega" do relato ao discurso lúdico garante certo efeito de experiência exitosa nas condições de interpretação assumidas.

Os pré-construídos caucionam a metaforização da experiência, apresentando-a como uma experiência exitosa. Essa experiência está calcada em: (1) o discurso lúdico na educação como forma de alcançar a atenção e a participação do aluno ("ministrar as aulas com músicas, cartazes, jornais, revistas e até pequenos teatrinhos, sempre enfocando o conteúdo que estávamos ensinando"). Sobre essa questão, cabem os seguintes questionamentos: como a música foi mobilizada no exercício? Pela descrição, parece ter sido apenas um pretexto, já que serviu para os alunos localizarem os pronomes presentes na letra e, também, causa de distração, porque a música foi ouvida, durante o tempo de realização do exercício. Os alunos gostaram da música ou da aula? Afinal é relatado que "eles ouviram atentos e até cantaram junto". Essa forma de distração deve ser considerada parte da aula? Algo a ser feito ou estar dentro do tempo de aula implica ser parte da aula?; (2) o discurso da inovação. Sobre este, podemos questionar: o que haveria de inovador no uso de letra de uma música para localizar pronomes nela? Ou no uso de imagem para produzir um texto?; (3) O discurso da afetividade. É preciso estabelecer laços de afeto e respeito, e isto foi conseguido com "a maneira diferente de aplicar conteúdos". Nessa parte do relato, um aspecto secundário ganha destaque e se sobrepõe ao pedagógico e ao didático. Do modo como está posto, "a maneira diferente" refere-se à forma de se relacionar com o aluno e não com a forma de ensinar-lhe algo.

Esse aspecto do relato é reforçado, na sequência, por: "participamos diretamente com os alunos das atividades comemorativas do calendário da escola, na semana da criança e dia dos professores, fizemos festinhas e realizamos muitas brincadeiras e recreações, os alunos gostaram muito". Mais uma vez, é apagada a questão da aprendizagem. O importante é os alunos terem gostado e não terem aprendido? Assim, irrompe no fio do relato o discurso lúdico como forma de "vender" a educação. Essas ações pedagógicas estão determinadas pelo discurso neoliberal que imputa à educação o valor de mercadoria. Assim, o aluno consome aquilo que lhe dá prazer, distração e entretenimento. Mas e o que lhe daria 
conhecimento e saber? Ou está em segundo plano ou está expurgado da sala de aula, o que parece um contrassenso.

Nesse mo(vi)mento enunciativo, a relatora é pregada ao discurso lúdico como forma de garantir o sentido exitoso de sua experiência e, assim relatando sua experiência, atender as coerções do regime enunciativo. A tônica da diferença em relação ao ensino tradicional é posta por meio do discurso lúdico e pela ausência de avaliação formal. Assim, a relatora faz significar que não é necessário propriamente ensinar, mas é necessário divertir os alunos. Não é à toa que a própria relatora aspeia o termo "ensinar" presente em: "percebi que apesar dos desafios e dificuldades que encontramos ainda é possível 'ensinar' e obter uma resposta positiva". A relatora se trai e distancia-se de "ensinar", explicitando a tensão vivida na experiência docente. Assim, é possível, inclusive, questionar se, em algum momento desse experiência docente, ela teria conseguido assumir o lugar de professor ou se teria permanecido no lugar de recreador.

Cabe ressaltar ainda que, ao concluir que "devemos dar a eles o que queremos que eles também nos dêem, (sic) "carinho e respeito", pode ser estabelecida uma relação implicativa entre "carinho e respeito" e "recreação", de modo que somente se dá "carinho e respeito" se é dado "recreação", "diversão" e "entretenimento". Determinada por essa relação, a relatora aboliu as provas e a avaliação, restringindo-se aos exercícios e às produções textuais realizadas e corrigidas em sala de aula. Assim procedendo, a relatora acredita que o aluno entenderá o conteúdo, porque teria ocasião de retomá-lo.

Vejamos, a seguir, o Terceiro Tempo de análise.

\section{Terceiro Tempo}

Vejamos, finalmente, como a narratividade (entre)tece o relato produzido no último Estágio Supervisionado vivenciado pela acadêmica e como o regime enunciativo determina a sua tessitura.

(RD5) Após observar as aulas no ensino médio conhecendo o perfil dos alunos e a didática da professora, confesso que me vi diante de um grande desafio, pois os alunos se mostravam bastante desinteressados e pouco participativos nas aulas./ Trabalhar com adolescentes e jovens, (sic) exige de nós enquanto professores (sic) algo muito maior do que um simples passar de conteúdo, pois é uma fase de descobertas, curiosidades etc., situações que podem afetar diretamente o desenvolvimento cognitivo dos alunos./ Pensando nisso optamos por trabalhar com aulas dinamizadas: audição de música, exibição de filmes, textos impressos comparando a linguagem, o contexto e os temas abordados. Traçando um paralelo entre os textos, criamos um espaço para conversação e discussão, de modo que os alunos pudessem expor suas opiniões sobre o assunto./ Dentre as dificuldades mais ocorrentes por parte dos alunos podemos observar em alguns, (sic) a dificuldade 
na compreensão textual, relacionar seus conhecimentos previamente adquiridos com as informações presentes no (sic) textos./ Nossa maior missão é trabalhar a elaboração da mensagem textual como instrumento de comunicação, incentivando o aluno a julgar fatos e situações além do senso comum, dando opiniões sobre estrutura marcas linguísticas argumentando sua opinião. Nessa nova experiência pude perceber que nós enquanto professores (sic) precisamos encontrar meio (sic) adequados para lidar com todos os alunos, os que têm dificuldades e os que têm desinteresse. Precisamos pensar estratégias que favorecem a inclusão, em função das necessidades específicas de acordo com a ideologia educacional./ Para nós professores de Português e Literatura (sic) podemos ensinar a gramática e a Literatura, simultaneamente dentro dos textos, contextualizando os exemplos para uma melhor compreensão da gramática dentro da estrutura textual./ Finalizando, acredito termos alcançado nosso objetivo, cientes de que precisamos melhorar muito ainda nossas metodologias e técnicas. Por isso considero a educação capaz de transformar tanto quem é educado quanto o educador, pois quando o professor é também aprendiz, a educação assume sua dimensão transformadora.

(Relato reflexivo sobre o Estágio Supervisionado em Língua Portuguesa IV)

Tomando por base a enunciação escrita em RD5, é perceptível que a relatora, já no início de seu texto, destaca a tensão que foi a realização da terceira etapa de observação e de regência no Estágio Supervisionado. Ela nomeia a vivência dessa etapa por meio do sintagma "um grande desafio". Essa nomeação abre horizontes para alguns questionamentos: em que consiste o "grande desafio"? O "grande desafio" seria pelo fato de serem alunos de ensino médio e não alunos de ensino fundamental, como ela estava acostumada nas outras etapas? O "grande desafio" seria em função exatamente do tipo de aluno e do tipo da didática da professora titular da turma? Ou seria por que, nessa etapa, por lidar com adolescentes e jovens, não poderia ocupar o lugar de recreador tão somente?

Nem o perfil de aluno nem a didática da professora são descritos no relato, de modo a fornecer argumentatividade para a nomeação produzida pela relatora. Ela, tendo a sintaxe como subterfúgio, já passa a valorar o comportamento dos alunos. Por meio das relações de adverbialização, "bastante desinteressados" e "pouco participativos", produz-se um efeito generalizante, predicando o comportamento de todos os alunos da turma. Também nesse relato a relatora deixa flagrar um modus operandi em sua escrita: ela metaforiza a experiência da observação, como o momento de identificar certos "problemas" do/no espaço de sala de aula, quase sempre relativos ao comportamento dos alunos; em seguida, metaforiza a experiência da regência como "exitosa". Está subjacente a esse modus operandi opor o mo(vi)mento da observação ao mo(vi)mento de regência, de tal modo que a diferença didática e pedagógica empreendida por ela possa ser significada como a causa da mudança de comportamento do aluno. Assim, é possível dizer que a relatora mantém, nos três tempos de Estágio Supervisionado, o mesmo funcionamento, embora a formulação seja diferente. 
A saída exitosa do relato, (im)posta pelo regime enunciativo implicado à situação de discurso e ao gênero relato reflexivo, está circunscrita a questões de metodologia de ensino e à escolha de materiais didáticos pertinentes. Daí o dizer: 'optamos por trabalhar com aulas dinamizadas: audição de música, exibição de filmes, textos impressos comparando a linguagem, o contexto e os temas abordados'.

Uma diferença significativa, mas explicável, deste relato para os anteriores é certo silenciamento do discurso lúdico. Tal parece ocorrer porque não cabe falar de "brincadeiras", "diversão" em relação ao Ensino Médio, uma vez que, além de se tratar de adolescentes e jovens, também é uma fase de preparação para a Educação Superior ou para o mercado de trabalho. Assim, a relatora não afirma mais que o uso de tais materiais, como audição de música, exibição de filmes, está em função da "recreação", da "diversão" e do "entretenimento" do aluno. No entanto, o efeito de ludicidade continua subjacente à formulação e, por isso, permanece significando em seu relato.

Um elemento novo no relato é a necessidade de se trabalhar textos. O próprio discurso oficial sobre o Ensino de Língua Portuguesa circula essa premissa. No entanto, não é descrito o que foi feito e como foi feito. Restringe-se apenas a dizer que usou textos para comparar a linguagem, o contexto e os temas abordados, além de sinalizar a criação de um espaço de conversação e discussão e insinuar que houve produção textual por parte dos alunos. Nessa perspectiva, equivale "educação transformadora" a "ensinar gramática e literatura por meio de textos", e isto porque, assim procedendo, o professor também aprende. Eis um ponto de tensão: como o professor pode aprender o que supostamente estaria ensinando no mo(vi)mento de ensinar?

\section{Considerações Finais}

No decorrer deste artigo, mostramos o modo como uma acadêmica do Curso de Letras de uma instituição federal metaforiza a experiência docente vivida no processo da escrita de relatos reflexivos sobre as etapas de observação e de regência do Estágio Supervisionado. Na esteira de Benveniste (2014), consideramos que a escrita, por supor um conjunto de abstrações, é sempre produzida por um sujeito. Há um manejo e uma apropriação das formas da língua pelo sujeito, no sentido de que ele torna essas formas aptas a emprego e ação específicos, sob as coerções do regime enunciativo implicado pela situação de discurso e pelo gênero em questão.

Esse manejo e essa apropriação conta com condições sócio-histórica e ideológicas específicas. Não há subjetividade solipsista; a subjetividade é resultado da experiência de linguagem, e essa experiência historiciza-se nas redes de memória que o constituem. Assim, no caso do relato reflexivo do relatório final de Estágio Supervisionado, o acadêmico é levado a escrevê-lo, sob a injunção de um regime enunciativo, de modo que sua narratividade resulte das condições de interpretação e dos processos de identificação que o constituem e que the impelem a fazer significar certas decorrências, inclusive em relação a certas questões 
teóricas tratadas na parte teórica do Estágio. O professor do Estágio, nessa relação discursiva, (com)porta as insígnias de certo discurso de que o Estágio precisa ancorar a articulação entre teoria e prática. Além disso, há as coerções da própria situação de discurso, tendo por base a contingência própria do espaço de sala de aula.

As enunciações escritas dos relatos analisados, por ter um eu-tu-ele-aqui-agora sob as referidas condições enunciativas, são constituídas por um regime enunciativo que acaba por expor o modo como a acadêmica lida com as coerções mencionadas ao longo do artigo. A perspectiva do regime enunciativo possibilita-nos tematizar o jogo entre unidade e dispersão da escrita, já que o modo como os saberes projetados sobre o que seria o acontecimento da aula, por exemplo, ganha uma narratividade na e pela escrita. Como mostramos analiticamente, a relatora, a cada etapa vivenciada do Estágio Supervisionado, vai metaforizando a sua experiência no processo de escrita, de modo a inscrever-se na narratividade exitosa que a situação demanda.

O processo de metaforização dos três tempos - (1) tempo do fato, (2) tempo da escrita e (3) tempo da leitura - faz funcionar um modus operandi nas enunciações escritas da acadêmica: produz uma oposição entre o mo(vi)mento da observação e o mo(vi)mento de regência para marcar a perspectiva de que ela empreende uma diferença didática e pedagógica, a qual seria responsável pela mudança de comportamento dos alunos. Eis, discursivamente, em operação, a constituição de uma narratividade sobre a suposta experiência exitosa ao longo dos Estágios Supervisionados. Contudo, a própria escrita faz trabalhar pontos de dispersão que mostram o jogo complexo entre os três referidos tempos.

Com a discussão que empreendemos neste artigo, estamos reivindicando a complexidade que o processo de metaforização da experiência circunscrita ao estágio exige. No caso, estamos considerando os Estágios como prática discursiva que encerra processos identitários sobre o savoir-faire do professor. Os acadêmicos, discursivamente, vão se filiando a espaços de interpretação determinados sobre esse savoir-faire. Não se trata de filiação controlada, plena nem bem-sucedida; ao contrário, são filiações contraditórias e que seguem impossibilitando o fechamento da formação do acadêmico.

\section{REFERÊNCIAS}

AGUSTINI, C.; LEITE, J. A relação entre teoria e prática no Estágio Supervisionado em Língua Portuguesa: uma abordagem enunciativa. ReVEL, v. 14, n. 11, ed. esp., p. 158-181, abr. 2016. Disponível em: <https://bit.ly/2MMovi5>. Acesso em: 03 mar. 2017.

BENVENISTE, E. Últimas aulas no Collège de France (1968 e 1969). Edição estabelecida por Jean-Claude Coquet e Irène Fenoglio. Tradução Daniel Costa da Silva et al. São Paulo: Editora Unesp, 2014. 
GRANGER, G. G. Objet, structure et significations. Revue Internationale de Philosophie, v. 73-74, n. 3-4, p. 251-290, 1965.

ORLANDI, E. (Org.). Instituição, relatos e lendas: narratividade e individuação dos sujeitos. Pouso Alegre: Univás; Campinas: RG Editores, 2016.

SIGNORINI, I. O gênero relato reflexivo produzido por professores da escola pública em formação continuada. In: SIGNORINI, I. Gêneros catalisadores: letramento e formação de professores. São Paulo: Parábola, 2006. p. 53-71. 